\title{
Law Enforcement in the Implementation of Law Number 40 of 2014 concerning Insurance Against the Impact of the Covid-19 Pandemic for the Indonesian Insurance Society
}

\author{
Ronald Listio $^{1}$, Zudan Arief Fakrulloh ${ }^{2}$ \\ \{ronald.lgs2909@gmail.com ${ }^{1}$, cclsis@yahoo.com ${ }^{2}$ \} \\ Universitas Borobudur, Jakarta, Indonesia ${ }^{1,2}$
}

\begin{abstract}
The state regulates the concept of legal protection in health insurance in the form of insurance. Insurance is an agreement between two parties, namely the insurance company and the policyholder. This study aims to analyze the role of the government in insurance regulation in Indonesia and to analyze Law Number 40 of 2014 concerning insurance, especially in the Covid-19 pandemic. The method used in this research is normative juridical by reviewing the regulations on insurance. The result of this study is that the state must take a role when both parties between the insurance company and the policyholder have problems during the pandemic. The state is obliged to provide a win-win solution by providing legal protection in a force majeure situation today.
\end{abstract}

Keywords: Legal Protection; Pandemic; Force Majeure

\section{Introduction}

The concept of legal protection is related to health insurance and economic assets regulated by the state in insurance. There is a regulation in Law Number 40 of 2014 concerning insurance.[1] Protection is an arrangement between two gatherings, in particular the insurance agency and the policyholder, which is the reason for getting charges by the insurance agency as a trade-off for :

a. provide remuneration to the safeguarded or policyholder because of misfortune, harm, costs brought about, loss of benefit, or legitimate responsibility to outsiders that might be enduring by the protected or policyholder because of the event of an unsure occasion; or

b. provide installments dependent on the demise of the guaranteed or expenses dependent on the existence of the safeguarded with benefits whose sum not really set in stone and in light of the aftereffects of asset the board.

The performance of the life insurance industry grew by $23.7 \%$ in June 2020 compared to revenue in June 2019. In the first quarter of 2020, the insurance industry was faced with the Covid-19 pandemic, which impacted general income.[2] Although the whole look of the global Covid-19 pandemic on the Indonesian insurance world is yet to be seen, we are presented with good news, namely a recovery in premium sales in June after experiencing a decline in the previous few months due to pandemic pressures.[3] 
The results of Lifespal.co.id's research comparing the OJK insurance statistics reports show that the recovery of gross premium income for life insurance in June 2020 exceeded the income value in June 2019.

In fact, despite having experienced a drastic decline in early 2020, life insurance premium income in June 2020 was the highest compared to January to June, both in 2019 and 2020. The graph above explains that the performance in June 2020 grew by $23.7 \%$. We reached revenue in June 2019.

In recent years, the growth of insurance or coverage in Indonesia has been disrupted due to the Covid-19 pandemic. Lower-middle class entrepreneurs demand insurance companies pay claims for their business interference. Currently, the Covid-19 pandemic has spread, and the possibility of increasing premiums could decrease. If the company has to pay for all claims rather than a business interruption, the insurance company may consider it bankrupt. During this period, there were 30 million claims from small and medium enterprises. Here the insurance company will experience a considerable loss.

There needs to be a role from the government and regulators because a decision like this cannot unilaterally decide whether it is an insurance company. When the Covid-19 pandemic is like this, it is impossible to restore financial conditions because it will burden insurance companies instantly. The risk of COVID-19 impacts the insurer so that the insured suffers a loss, especially on the insurance disruption policy.[4]

Meanwhile, the Insurance Law stipulates that insurance objects in Indonesia can only be insured with insurance companies or sharia insurance companies in Indonesia. The closure of such insurance objects must pay attention to optimizing the capacity of insurance companies, sharia insurance reinsurance companies, and domestic sharia reinsurance companies. The government and the Financial Services Authority (OJK) must encourage domestic insurance and reinsurance capacity. With insurance protection, it is hoped that there will be peace for the community in carrying out activities and enabling business innovation which will ultimately create mutual prosperity.

General policies in the context of developing the use of insurance and reinsurance to support the national economy include foreign ownership of Insurance Companies, capacity building for domestic insurance, sharia insurance, reinsurance and sharia reinsurance, as well as the provision of fiscal facilities to individuals, households, and businesses - micro, small and medium.

In this challenging time of the COVID-19 pandemic, it is essential to pay attention to the health and the economy of the citizens and the country.[5] With the high potential for transmission, special handling is needed for people affected by COVID-19. Special treatment and many patients cause the cost of treating infected people to be very high. Even from several sources, if people are infected, the prices for treatment in private hospitals are up to $\mathrm{Rp} 500$ million. Of course, this figure is not cheap; therefore, many people are starting to make themselves aware of buying protection in health insurance for themselves and their families but do not know exactly what insurance is.[6]

Referring to the applicable law Article 1 paragraph 1 of Law Number 40 of 2014 concerning Insurance states that:

Protection is an understanding between two gatherings, specifically the insurance agency and the policyholder, which is the reason for getting expenses by the insurance agency as a trade-off for giving repayment to the guaranteed or policyholder because of misfortune, harm, costs brought about, lost profits, or legal liability. to third parties that may be suffered by the insured or the policyholder due to the occurrence of an uncertain event; or provide payment 
based on the death of the insured or compensation based on the life of the insured with a predetermined amount of benefit."

From this definition, it can be concluded that there are two types of insurance, namely general (loss) and life insurance. The most fundamental difference is that the number of dependents from loss insurance is indemnity. It is limited by the amount of loss suffered by the insured and cannot be determined in advance. Meanwhile, in life insurance, the amount of coverage is compensation to be determined in advance. However, the principle remains that the insured will pay a premium, and the insurance company (the insurer) will provide coverage if the risk occurs. In practice, health insurance can be defined as coverage between the insurer and the insured if the insured is sick and requires medical expenses. This insurance can be provided by the type of life and loss insurance company.

The agreement formed between the insurer and the insured can be said to be an insurance agreement where the agreement's details will be written in the insurance policy. The policy, in this case, will regulate in fact which events are included in the coverage and which are excluded. That way, to find out whether the insurance company will bear the cost of treating the disease from the COVID-19 virus or not, you must carefully read the policy. Then if it is included, it must also be believed that the condition from the epidemic is included in the coverage as referred to in this case considering the President of the Republic of Indonesia through Presidential Decree Number 12 of 2020 Determination of Non-Natural Disasters Spreading Coronavirus Disease 2019 (Covid-19) as a National Disaster and the stipulation of COVID-19 19 as a Pandemic by the World Health Organization (WHO).[7]

If it turns out that COVID-19 is included in the exception to the policy, the insurer is not responsible for providing coverage if the insured is exposed to COVID-19. In this condition, the insured is advised to contact the insurer to request a policy extension. Of course, this expansion must be approved in advance by the insurer and accompanied by additional premiums.

As stated in Article 53 of Law no. 40 of 2014, the policy guarantee program guarantees the return of part or all of the rights of the policyholder, the insured, or participants of an insurance company or sharia insurance company whose business license is revoked and liquidated. As long as the policy guarantee has not been established, the guarantee provisions for the policyholder are still in the form of a Guarantee Fund originating from the wealth of the insurance company.

In recent years, using technology has become the primary support for the world of marketing in all companies, including insurance. The use of telemarketing in the world of insurance has become a practical thing in attracting participants combined with cooperation with banks that have prospective customer data. It is not impossible for insurance telemarketing to call all customers, which is just a waste of time and telephone costs. This is what makes the opportunity for a corporation to become an economic crime syndicate due to cooperation that is considered legal based on a civil agreement which is viewed as a law.

By using Misbruik van Omstadigheden, most insurance companies can take advantage of contractual agreements.[8] Misbruik van Omstadigheden is a standard law legal system term, so it is a foreign term in the Indonesian legal system. In the field of civil law, this term is often equated with a defect of will.

If the policy suffers a business interruption, the insurer will compensate for the gain due to the constraint. However, the obstacles referred to here are physical disturbances in the form of fires and accidents. Insurers who experience losses need to assess losses due to the Covid-19 pandemic. Both the position of the insurer and the regulator can be identified.[9] 
If an event causes a loss (resulting in the risk of failure), the insured concerned will be compensated according to the insured amount. In practice, the losses incurred are partial (partial loss), not all of them are total losses. Thus, the insured holds insurance intending to get compensation payments for the damage he suffered.

There needs to be awareness from the public about the importance of protecting against various kinds of risks. The risk can befall insurance users at any time, which is one factor causing the high number of insurance users. Insurance is a noble business, even if you don't realize it. That's because insurance services are only helpful and of high value when people are at a critical time and need financial assistance. If the claim is not under the agreement procedure made by both parties, it will benefit the insurance company that provides insurance services. There are still many people who do not understand or understand the use of insurance. The public also does not understand in detail the laws and regulations.

When viewed today with the development of the era and science technology is increasing day by day. Making human needs increase and technological developments cause this. In the business sector, competition among entrepreneurs is also getting higher. So, the level of risk that will occur in every human activity can be at any time. Insurance is the right way to solve problems in the household to face the hazards that will happen. Risks that can occur such as accidents, fires, and death. The insurance policy plays an important role when the claim (compensation) by the insurance company is paid to the insurer.

\section{Methods}

The approach used in this research is the normative research method, which is commonly used as a research method in the legal field. It will not be sufficient to examine the focus of this research in an ideal and comprehensive manner.[10] To answer the problems that are the focus of this research, in addition to a comprehensive review of the laws and regulations relating to prisons, including laws and regulations that can threaten them, in responding to and implementing the provisions of these laws and regulations.[11]

The research method used as described in the previous paragraph, namely the normative process, five approaches will be used in this research, namely: (1) the statutory approach, (2) the conceptual approach, (3) the philosophical approach, (4) the comparison, and (5) a casuistic approach. A philosophical approach is used for Law No. 40 of 2014 concerning insurance and the laws and regulations below which regulate insurance, as will be seen in the next stage using a statutory approach. The conceptual approach will build a more operational understanding of the various definitions of trademarks and the Indonesian legal framework and then be applied in the analysis process using a comparative and casuistic approach.

This research was conducted using normative juridical research methods, namely analysis on favourable legal rules and legal principles by evaluating relevant legal rules (laws and regulations).

The research's specification for this writing is "normative legal research", namely by examining the quality and truth of a legal norm. Study with this method aims to determine whether the rule of law follows legal standards, whether criteria in the form of prohibitions or orders follow legal principles, and whether a person's actions follow legal norms or regulations.

There are two types of data regarding where it was obtained, namely primary data and secondary data. Primary data is data obtained directly from the community. At the same time, 
secondary information is data obtained from the literature. In this case, the data collection technique carried out by document study or literature study is meant by literature.

\section{Discussion}

\subsection{The role of the government in terms of regulations related to insurance in Indonesia}

The Insurance Law stipulates that insurance objects in Indonesia can only be insured with insurance companies or sharia insurance companies in Indonesia, and the closure of such insurance objects must pay attention to optimizing the capacity of insurance companies, sharia insurance companies, reinsurance companies, domestic sharia reinsurance companies. The government and the Financial Services Authority (OJK) encourage domestic insurance and reinsurance capacity. With insurance protection, it is hoped that there will be peace for the community in carrying out activities and enabling business innovation which will ultimately create mutual prosperity.

The insurance company as a financial institution that collects public funds also allows the accumulation of funds that can be used to finance national development activities. In an increasingly open and rapidly developing economy, insurance services or risk management are increasingly diverse and of high quality by an Insurance Company that is healthy, reliable, trustworthy, and competitive. For this reason, Insurance Companies need to be built with solid capital sources, both domestically and from abroad. This means that insurance as a business activity in the service sector today must reach a broader market, tackling the need for domestic risk management and tackling risks from inter-country activities.

The formation of the world trade organization (WTO) is the result of the final agreement of the Uruguay round by 122 member countries in Marrakesh. The hope of the formation of the WTO is the assumption that with increased production, there will be an increase in investment which will at the same time create jobs which in turn will improve people's income.

Another article states that GATT, as part of the United Nations (UN) organization, aims to protect the balance of interests between members in international trade relations. It is hoped that GATT can function as a stabilization tool regarding import duty tariffs and a forum for international trade consultations.

The formation of the world organization (WTO) is an institution that protects the mechanism of international trade in both goods and services. According to Muhammad, international trade occurs when the parties in the transaction of goods and services trade are carried out by different nationalities, which are referred to as exporters (traders) and importers (sellers).

The insurance business opportunity in the era of globalization is enormous because every activity will always face risks. Even each country will be able to take this opportunity in the land of origin and invest in other countries, especially in the insurance sector. According to Martin Khor Kok Peng, industrialized nations are trying to dominate the third world economy by including new themes, namely services (GATS), Investment (TRIMS) and TRIPS in the GATT agenda. The impact of this regulation is that transnational companies from developed industrial countries in the service sector, whether they are engaged in banking, insurance, to consulting services, operating in Indonesia, must be treated the same as domestic service companies or entrepreneurs. This means that in making laws and providing business 
opportunities, including in the insurance sector, it must be applied without discrimination between domestic and foreign parties, limiting foreign entrepreneurs' business movements.

Barriers to the development of the competitiveness of the national insurance industry include limited capital, limited quality human resources, employee productivity levels, the integrity of insurance business actors, high operational costs, too low premiums, and so on: namely laws and regulations, cultural factors, state factors and government role factors.

Referring to the results of the research by A Junaidi Ganie above, it shows that insurance in Indonesia still has a lot to be improved and a very significant improvement is needed, both in-laws and regulations in the insurance sector, culture and circumstances as well as the role of the government, to be able to compete with other countries. In other countries, if not, the insurance business opportunity will be exploited by foreign parties, for example, with the life insurance company PT Prudential Life Assurance, loss insurance (general) PT Avrist Assurance which is entirely developed in Indonesia. An Indonesian insurance company that can survive and thrive is PT Asuransi Sinar Mas as general insurance.

Joint Life Insurance (AJB) Bumiputra 1912, which can survive until now in Indonesia as well. However, these insurances cooperate with international reinsurance companies Munich Re, Swiss Re, Hannover Re, Toa Re, etc., and National Reinsurance Companies, namely Tugu Re, Nasional Re Marein and Reindo.

As mentioned above, Indonesia's ability to increase competitiveness in the insurance business is a challenge that must be faced by improving several factors. As a nation that is part of the world community, Indonesia must meet the challenges of competitiveness in the insurance business sector. The insurance business is an opportunity that must be exploited as much as possible to improve the welfare of the community, and insurance is an effort to transfer risks related to the property and life of each person in all life activities that are carried out concerning the economy, socio-culture and even politics. Therefore, all infrastructure related to the insurance business must be improved, including the laws and regulations governing insurance issues.

\subsection{Insurance Regulations in Indonesia Regarding Pandemic Conditions}

Indonesian insurance law cannot be separated from the history of other legal regulations that apply in Indonesia. Regarding the history of insurance law in Indonesia, it cannot be severed from the provisions of Civil Law and Commercial/Company Law originating from the Netherlands with the enactment of the Civil Code (from now on briefly written KUHPdt), which is a translation of the Dutch civil law book Burgerlijke Wetboek, which turned out to be from France (Code Civil -Code de Commerce France), based on the Transitional Rules of the 1945 Constitution, this codification remains in effect until there are regulations that amend it.

The enactment of Law Number 40 of 2014 concerning Insurance on October 17, 2014, is a newly legal product that regulates insurance in Indonesia and abolishes the validity of Law Number 2 of 1992 concerning Insurance Business. As a legal product, it is expected to be able to answer the shortcomings of the old regulations and be able to adapt to the development of science and technology in the insurance sector, where there are developments in science and technology, there will be risks faced following the product itself, to various There is a need for management in a business to provide social protection for everyone, providing solutions in dealing with risks.

Concerning insurance law in Indonesia, the ownership of insurance companies is contained in Chapter III entitled Forms of Legal Entities and Ownership of Insurance Companies regulated in Article 7 Paragraph (1). Insurance companies can only be owned by: 
a. Indonesian citizens and Indonesian legal entities which are directly or indirectly whollyowned by Indonesian citizens; or

b. Indonesian citizen and Indonesian legal entity as referred to in letter a, together with foreign citizen or foreign legal entity which must be an Insurance Company that has a similar business or a holding company whose one of its subsidiaries is engaged in the same type of Insurance Business.

Article 7 Paragraph (2) stipulates that: Foreign nationals, as referred to in paragraph (1) letter b, may become owners of an Insurance Company only through transactions on the stock exchange.

Article 7 Paragraph (3) stipulates that: Further provisions regarding the criteria for foreign legal entities and ownership of foreign legal entities as referred to in paragraph (1) letter b and ownership of foreign citizens as referred to in paragraph (2) in an Insurance Company shall be regulated in a Government Regulation.

The implementation of this provision is further regulated in a Government Regulation; of course, the regulation in question does not yet exist. Meanwhile, the Government Regulation in question does not yet exist, so it is still possible to use the previous Government Regulation, including other implementing regulations, as long as it does not conflict with the contents of the law on insurance which was just enacted on October 17, 2014, a few months ago.

From the explanation of Article 7 Paragraph (1) above, the relationship of foreign parties in the ownership of insurance companies in Indonesia is in the context of solid capital accumulation, limited both qualitatively and quantitatively. Qualitatively, for an Insurance Company that has business experience in its field, it is expected that there will be a transfer of capital and transfer of knowledge and technology to the Indonesian side. The ownership limits of foreign legal entities in the Insurance Company are consulted with the House of Representatives of the Republic of Indonesia and the Financial Services Authority.

The existence of new insurance law in Indonesia with the linkage of foreign parties in the ownership of insurance companies based on the quality and quantity of the foreign company itself, of course, it is interesting to conduct a more profound study by looking at the legal theories of previous legal experts, as well as by looking at the regulations. Implementation of the old insurance business, because after all, these implementing rules are still valid as long as they do not conflict with the Insurance Act as a law.

As an activity carried out jointly, of course, there must be integration between the parties. Talcott Parsons places law as one of the sub-systems in the social system, the other social subsystems in question are culture, politics, and economics, the legal sub-system functions maintain ideal patterns in society, the law refers to rules as the rules of the game (power of the game), conflict-prone situations must be handled by law through its integration function so that each sub-system runs harmoniously and synergistically for the sake of system sustainability, Parsons placing the law as the main element in integration. Law as a means of integration as Parsons' theory, in terms of running a joint venture jointly between Indonesian citizens and foreign parties, the provisions of the Insurance Law and its implementing regulations must serve as guidelines between the parties.

Apart from being a means of integration, the law must control change so that the law can be used as a tool for change. According to Mochtar Kusumaatmadja, who was inspired by the concept of Roscoe Pound (1986), the law as a means of renewal in community development, the idea in question is "law as a tool of social engineering". Suppose the law is only a concept of rules/norms. In that case, it cannot solve various problems now and in the future, because society will continue to develop under the development of science and technology that surrounds it. 
From the explanation of the qualitative criteria for the participation of foreign parties in the ownership of insurance companies in Indonesia, it is based on: 1) The foreign party must be a legal entity, meaning as a partnership company, which is subject to the laws of the country of origin, 2) Have a similar insurance business or a holding company in which one of its subsidiaries is engaged in the same type of Insurance Business, and 3) Has business experience in the insurance sector.

The determination of these qualitative criteria to share experiences in the management of the insurance business, share technology in addition to attracting investment from foreign parties these criteria are almost the same as the provisions for the implementation of insurance in the insurance business law, which has been declared invalid, namely the explanation of Article 8 Paragraph ( 2) from Law Number 2 of 1992 concerning Business.

Insurance that has been declared is no longer valid since the enactment of the new insurance law. That an insurance company established or owned by a domestic insurance company and a foreign insurance company having similar business activities is intended to foster a more professional implementation of insurance business activities, as well as to make the process of technology transfer more likely so that the involvement of foreign parties in the insurance business in Indonesia can be done by: a) a foreign Reinsurance Company with a domestic Loss Insurance Company can establish a Company with a Loss Insurance Company or a Reinsurance Company, and b) a foreign Loss Insurance Company with a domestic Reinsurance Company can establish a Loss Insurance Company or a Reinsurance Company.

Based on the explanation of the provisions of Article 8 Paragraph (2), it can be seen that the conditions of the qualitative criteria in the new regulations on foreign ownership in the implementation of insurance businesses in Indonesia still follow the old provisions.

Indonesian law must be a law that brings the most significant benefit to the people, directed at realizing the participation of all the people and the idea of justice because justice is in the interests of the people, not for specific interests, especially the authorities so that a review of the insurance law is to examine the contents of the articles contained in the law. Relating to the involvement of foreign parties as business actors, as well as the involvement of the government as the organizer of supervision and guidance, and the interests of the community as parties who will receive the impact of the enactment of a regulation.

About justice can be learned from the theories of Plato, Hans Kelsen, H.L.A Hart, John Stuart Mill and John Rowls. Plato sees that justice produces the value of the idea of goodness, seen from its usefulness, goodness is the substance of justice. According to Salim,[12] if this theory is applied to the provisions of the insurance law which are run in a joint venture, then the policy is taken based on benefits to attract capital from foreign parties, which will be utilized in a more significant sector, not only the profits of Indonesian entrepreneurs in general. Individuals, but its benefits to develop the Indonesian economy through policies in the economic field by making the maximum use of foreign capital, for other benefits, such as the tax sector.

Another case is the theory of justice from John Stuart Mill, that judge is placed on protecting claims. The purpose of shares is to increase welfare and hold promises equally, which means that the position of people is equal (equal in height), a balanced position. John Stuart Mill's theory of justice is the same as that proposed by Hart, that the principle of justice is that individuals have an equal place with one another.[13] This theory views equality as high and balanced, individually, that joint ownership of shares can be carried out in a balanced manner by determining the same capital ownership, assuming 50\% (fifty per cent) of the total, so that the profits will be the same, between Indonesian entrepreneurs with foreign entrepreneurs. On the individual side, entrepreneurs, especially the Indonesian side, will get a 
balanced income for welfare as citizens as a right protected in the 1945 Constitution Article 27 paragraph (2), so that Indonesian citizens are not only entitled to work but also have the right to achieve life worthiness as a right. Human rights and to earn a decent living as a human being, the opportunity to fulfil the Constitution does exist, but in the long term, and is carried out in stages. Still, the laws and regulations in the insurance sector provide more excellent opportunities for foreign entrepreneurs up to $80 \%$, even if the parties can agree upon it in terms of capital, then the foreign party has the chance to make a more vital capital contribution.[14]

Balance is not always interpreted equally but must be seen in terms of its importance, in this case, the theory of justice in particular about Rawls' two principles of justice. The benefit of all, government intervention because of the state's interest in the welfare of society, even though this theory ignores equal equality. As applicable to the share ownership of BUMN in the form of a company, the state owns a minimum of $51 \%$ and the private sector a maximum of $49 \%$ as the shareholder of a BUMN.

The renewal of a law does not only look at the incompatibility of the contents of the articles in the law. Still, it must consider Indonesian legal politics, national identity as enshrined in Pancasila and the 1945 Constitution.

The legal politics that will be or have been implemented nationally by the Government of Indonesia includes: first, the development of laws with the core of making and updating legal materials so that they are following the needs; second, the implementation of the existing legal provisions has included the affirmation of the function of institutions and the guidance of law enforcement officers, from this understanding it can be seen that legal politics provides for the process of making and implementing laws that can indicate the nature and direction in which the law will be built and enforced.

The provision of opportunities to foreign parties who will do business in Indonesia must be considered carefully in providing signs as a legal umbrella that will be used as a reference, not only to bring in foreign investors, with the reason to stimulate business in the country, in this case, the state has interests as mandated in Pancasila, the 1945 Constitution and Indonesian legal politics, the welfare of the Indonesian people must be considered, in this case, it is necessary to limit the capital ownership of foreign parties who will conduct insurance business in a joint venture, how much of their capital can be rolled out together with indigenous entrepreneurs, at least maximum the same as those owned by Indonesian citizens or Indonesian legal entities.

The renewal of an insurance law relates to the involvement of foreign parties in the provision of insurance in Indonesia in line with the development of international business whose activities cross national borders not only regarding international trade and manufacturing abroad but also related to the development of a developing service industry, such as transportation. Tourism, banking, advertising, construction, retail trade, wholesale trade, and mass community. Can be added, including the business in the insurance sector, because every aspect related to any business and anywhere is constantly faced with risks, also with the existence of trade carried out through cyberspace (e-commerce via the internet), and even then it can be carried out by intermediary parties. Nation.

The absence of implementing regulations for conducting insurance business based on the provisions of the new Insurance Law can be learned from the old insurance implementation regulations, which are declared still valid as long as they do not conflict with the new law. As an implementing regulation of the previous (old) Insurance Business Law, it is contained in Government Regulation of the Republic of Indonesia Number 73 of 1992 concerning the Implementation of Insurance Business (has been amended several times).[15] 
Foreign parties' direct participation in insurance companies follows the provisions on the amount of capital that must be paid up in certain types of insurance businesses. In the conditions on general requirements for licensing insurance businesses, it is regulated that the amount of capital owned by foreign parties is a maximum of $80 \%$ (eighty per cent) Article 6 paragraph (3) The PP on the Implementation of Insurance Business, continued in the next paragraph, section (4), that in carrying out the joint business with foreign parties, an agreement between shareholders must contain an agreement regarding the plan to increase share ownership of the Indonesian side. The increase in share ownership of the Indonesian party as referred to in Article 6 paragraph (4) of the PP on the Implementation of Insurance Business as written above that within 20 (twenty) years must be at least $51 \%$ (fifty-one per cent).

Further study by reviewing the implementing regulations for the implementation of insurance Article 6 Paragraph (4) stipulates the provision of opportunities for Indonesian shareholders in cooperation agreements with foreign parties, further regulated in the Decree of the Minister of Finance of the Republic of Indonesia Number 223/KMK.017/1993 concerning Business Licensing Insurance Companies and Reinsurance Companies, in discusion concerning Other Provisions it is written that: Increasing share ownership of the Indonesian party as referred to in Article 6 Paragraph (4) Government Regulation Number 73 of 1992 (Implementation of Insurance Implementation) within a period of 20 (twenty years) ) to be at least $51 \%$ (fifty-one per hundred). An extended time in providing more profits for the Indonesian side, which means that at the beginning of the establishment of a foreign company, an unfamiliar party can have a larger share than the Indonesian side, the size of the claim will affect the amount of profit achieved by the company, the Indonesian side will only be able to enjoy greater profits after reaching 20 (twenty years later) this ownership shows that foreign parties will gain more significant profits, this deviates from the national legal politics of the Indonesian nation in the welfare of Indonesian citizens/people, namely a just, prosperous, prosperous society based on Pancasila and the Constitution. 1945.

Law as a norm must be obeyed, but whether the example brings justice, especially for the Indonesian side who run a business in Indonesia. A judge does not have to be equally balanced, but justice can be seen from the balance of interests, in this case, the Indonesian people's and government's interests. So that the determination of quantitative criteria for foreign ownership of capital in the old insurance provisions cannot be maintained for use in the new insurance administration rules, namely with the enactment of Law Number 40 of 2014 concerning Insurance.

Law Number 40 of 2014 concerning Insurance is a legal regulation that covers general insurance activities in Indonesia as a guideline for implementing insurance businesses in Indonesia, including the involvement of foreign parties to participate in the insurance business in Indonesia. As described above, this Insurance Law can only take effect after implementing regulations are drawn up for 2 (two) years and 6 (six) months, so that all implementing rules of the previous insurance administration regulations are still declared valid as long as they do not conflict with the law. -New Insurance Act.

\section{Conclusion}

The challenges faced by Indonesia in the insurance business in the era of the COVID-19

pandemic are increasing competitiveness in the national insurance business and expanding the role of law, community culture, and trust in the federal insurance business, as well as the part 
of the government in carrying out guidance, supervision and protection to the community, especially in implementing insurance. The existence of Indonesian insurance law, especially the ownership of companies by foreign parties in the era of globalization, still has to be formulated in detail in the implementation of the insurance business in Indonesia, especially regarding the ownership of foreign parties in the performance of the insurance business in Indonesia, both qualitatively and quantitatively.

\section{References}

[1] UU RI No.40 Tahun 2014 tentang Perasuransian. .

[2] D. Yudhanegara and J. M. Villanueva, "Literasi Asuransi Pada Masa Pandemi Covid19," Abdimas Siliwangi, vol. 4, no. 2, pp. 49-59, 2021.

[3] T. Rastuti, Aspek Hukum perjanjian asuransi. MediaPressindo, 2016.

[4] M. Ubaidillah and R. H. Syah Aji, "Tinjauan Atas Implementasi Perpanjangan Masa Angsuran Untuk Pembiayaan Di Bank Syariah Pada Situasi Pandemi Covid-19," Islam. Bank. J. Pemikir. dan Pengemb. Perbank. Syariah, vol. 6, no. 1, pp. 1-16, 2020, doi: 10.36908/isbank.v6i1.159.

[5] R. Listio and F. Santiago, "Analysis of the Role of Insurance Law of the Impact of the Covid-19 Pandemic for Indonesian Community Insurance," 2021, doi: 10.4108/eai.6-32021.2306294.

[6] F. Santiago, "Credit Relaxation Policy During Covid-19 Reviewed from the Force Majeure Aspect," 2021, doi: 10.4108/eai.6-3-2021.2306389.

[7] F. Dalimartha and F. Santiago, "Banking Legislation Renewal as a Preventive Effort of Banking Corruption Crime," in ICLSSEE 2021, 2021, no. 1, doi: 10.4108/eai.6-32021.2306201.

[8] D. Siswanto, "Dampak Resiko Keuangan Dalam Bisnis Jasa Keuangan Perusahaan Asuransi Jiwa di Era Pandemi Corona," KarismaPro, vol. 2, no. 1, pp. 1-13, 2021, doi: 10.53675/karismapro.v2i1.71.

[9] L. M. Friedman, Contract law in America: a social and economic case study. Quid Pro Books, 2011.

[10] D. Lee, "Research consultations: Enhancing library research skills," Ref. Libr., vol. 41, no. 85, pp. 169-180, 2004, doi: 10.1300/J120v41n85_13.

[11] W. L. Neuman and B. Wiegand, Criminal justice research methods: Qualitative and quantitative approaches. Allyn and bacon Boston, 2000.

[12] D. N. Wijaya, “John Locke Dalam Demokrasi," J. Sej. dan Budaya, vol. Tahun Kede, pp. 13-24, 2014, [Online]. Available: http://journal.um.ac.id/index.php/sejarah-danbudaya/article/view/4751.

[13] P. Bourdieu, "The Force of Law : Toward a Sociology of the Juridical Field The Force of Law : Toward a Sociology of," vol. 38, no. 5, 1987.

[14] E. E. Supriyanto, "Revitalization of Pancasila as a Solution to The Problems Faced by The Indonesian Nation," J. Pendidik. Nusant., vol. 1, no. 2, pp. 52-61, 2021.

[15] F. Firdaus, "Majeure Majeur Dalam Usaha Asuransi," in Force Majeure in Law, 2021, pp. 47-66. 